Vol 12, Issue 1, 2019

\title{
A NEW REVERSED-PHASE HIGH-PERFORMANCE LIQUID CHROMATOGRAPHY METHOD FOR THE SIMULTANEOUS ESTIMATION OF SERRATIOPEPTIDASE AND DICLOFENAC SODIUM IN BULK AND TABLET DOSAGE FORM
}

\begin{abstract}
MANASI KULKARNI B ${ }^{1,2 *}$, ANAGHA JOSHI $\mathrm{M}^{3}$
${ }^{1}$ PhD Research Scholar, Punnaiyah Ramajayam Institute of Science and Technology, PRIST Deemed to be University, Thanjavur, Tamilnadu, India. ${ }^{2}$ Asst. Professor, Department of Pharmaceutical Chemistry, SCES's Indira College of Pharmacy, Tathawade, Pune, Maharashtra, India. ${ }^{3}$ Principal, SCES's Indira College of Pharmacy, Tathawade, Pune, Maharashtra, India. Email: mansi.wagdarikar@indiraicp.edu.in
\end{abstract}

Received: 03 August 2018, Revised and Accepted: 10 September 2018

ABSTRACT

Objective: The objective is to study the development of a simple, rapid, specific, precise, and accurate reversed-phase high-performance liquid chromatography (RP-HPLC) method for the simultaneous estimation of serratiopeptidase (SER) and diclofenac (DC) sodium in bulk and tablet formulation.

Methods: RP-HPLC method was developed for the simultaneous estimation of SER and DC sodium in tablet formulation. The separation was achieved by Kromasil C18 column ( $250 \mathrm{~mm} \times 4.6 \mathrm{~mm}, 5 \mu \mathrm{m}$ particle size) with phosphate buffer pH-7 and o-phosphoric acid:methanol:acetonitrile (5:4:1\% $\mathrm{v} / \mathrm{v} / \mathrm{v}$ ). Flow rate was maintained at $1 \mathrm{~mL} / \mathrm{min}$ and $\mathrm{UV}$ detection was carried at $270 \mathrm{~nm}$.

Result: For RP-HPLC method, the retention time for SER and DC sodium was found to be $3.3833 \mathrm{~min}$ and $8.1667 \mathrm{~min}$, respectively. The method was validated for accuracy, precision, and specificity. Linearity for SER and DC sodium was in the range of 5-50 $\mathrm{g} / \mathrm{ml}$.

Conclusion: The developed RP-HPLC method is simple, accurate, rapid, sensitive, precise, and economic. Hence, this method can be employed successfully for the estimation of SER and DC sodium in both bulk and tablet dosage forms.

Keywords: Serratiopeptidase, Diclofenac sodium, Methanol, Acetonitrile, Phosphate buffer pH-7, O-phosphoric acid, Reversed-phase highperformance liquid chromatography.

(C) 2019 The Authors. Published by Innovare Academic Sciences Pvt Ltd. This is an open access article under the CC BY license (http://creativecommons. org/licenses/by/4. 0/) DOI: http://dx.doi.org/10.22159/ajpcr.2019.v12i1.28857

\section{INTRODUCTION}

Serratiopeptidase (SER) is a proteolytic enzyme (protease) produced by Enterobacter Serratia sp. E-15. This microorganism was originally isolated in the late 1960s from silkworm Bombyx mori L. (intestine). SER is present in the silkworm intestine and allows the emerging moth to dissolve its cocoon. SER is produced by purification from a culture of Serratia E 15 bacteria. SER is primarily indicated in the condition of hematoma, inflammation, edema osteoarthritis, and thrombosis. Diclofenac (DC) sodium is sodium 2-[(2, 6-dichlorophenyl)-amino] phenylacetate. It is a synthetic non-steroidal anti-inflammatory agent with analgesic, anti-inflammatory, and antipyretic activity. Its mechanism of action is associated principally with the inhibition of prostaglandin synthesis (specifically, inhibition of cyclooxygenase). DC sodium is administered to reduce inflammation and as an analgesic reducing pain in conditions such as arthritis or acute injury. It can also be used to reduce menstrual pain, dysmenorrhea (Figs. 1 and 2) [1-4].

Literature survey reveals few methods for the simultaneous estimation of SER and DC sodium in the combination considered in this work and other combinations. This initiates a need for more rigorously studied and competent reversed-phase high-performance liquid chromatography (RP-HPLC) method development and validation for SER and DC sodium in bulk and tablet dosage form.

\section{METHODS}

1. DC sodium (Zydus Cadila, PTC, Thane)

2. SER (Analab Fine Chemicals)

3. Marketed formulation: Emanzen-D (EMCURE Pharmaceuticals Pvt. Ltd.)

4. Acetonitrile (HPLC grade, Merck Ltd.)
5. Methanol (HPLC grade, Merck Ltd.)

6. Phosphate buffer pH- 7(HPLC grade-Merck Ltd.).

Instruments

- Model: Cyberlab LC-100 HPLC (binary gradient system)

- Injector: $20 \mu \mathrm{L}$

- Detector: UV detector

- Software: Workstation -100

- Analytical balance: Shimadzu, AX 200

- Sonicator: Dakshin (ultrasonicator)

Chromatographic condition

- Analytical column: Kromasil C18 column (250 mm × $4.6 \mathrm{~mm}, 5 \mu \mathrm{m}$ particle size)

- Mobile phase: phosphate buffer (pH-7) with o-phosphoric acid (OPA):methanol:acetonitrile (ACN) (5:4:1\% v/v/v)

- Injection volume: $20 \mu \mathrm{L}$

- Flow rate: $1 \mathrm{~mL} / \mathrm{min}$

- Detection wavelength: $270 \mathrm{~nm}$

- Retention time: SER 3.38 min and DC 8.16 min.

Preparation of standard solutions

Preparation of diluent

Phosphate buffer pH 7 with OPA, methanol, and acetonitrile $(5: 4: 1 \% \mathrm{v} / \mathrm{v} / \mathrm{v})$ mixtures was used as diluents and was filtered through $0.22 \mu \mathrm{m}$ nylon filter under vacuum condition. Then, it was sonicated for $15 \mathrm{~min}$ and further used for the mobile phase preparation.

Preparation of SER and DC stock solution

Accurately weighed quantity of DC sodium equivalent to $10 \mathrm{mg}$ and SER $(10 \mathrm{mg})$ was transferred into two separate $10 \mathrm{~mL}$ volumetric flasks. 


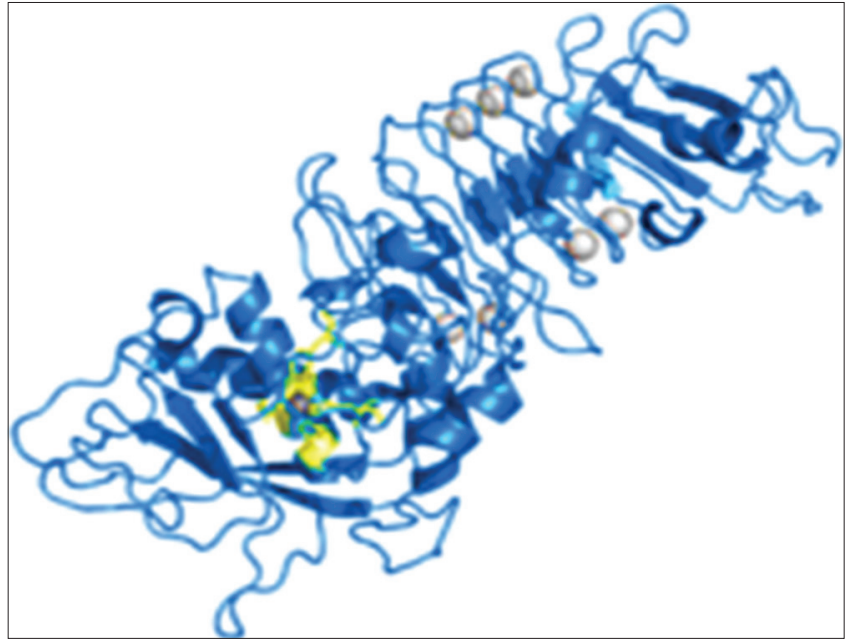

Fig. 1: Crystal structure of serralysin with coordinated zinc (gray) and calcium (white)

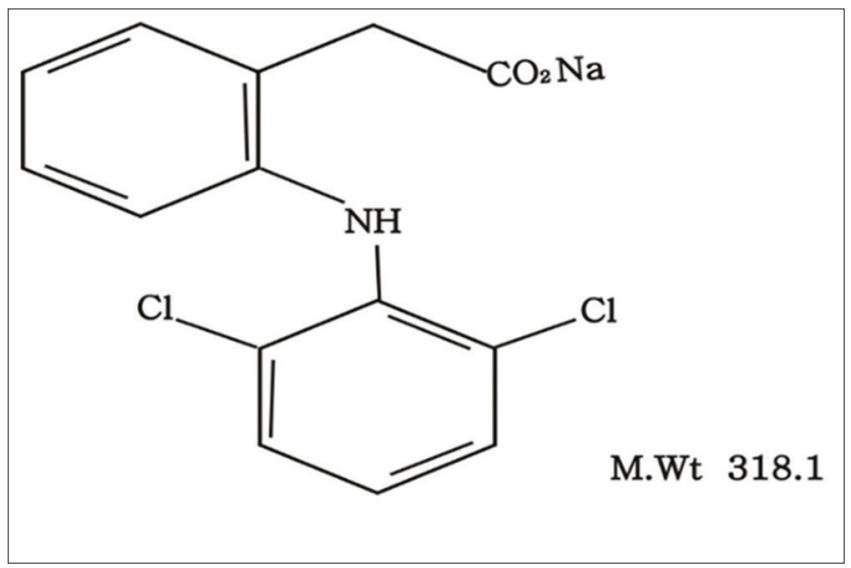

Fig. 2: Structure of diclofenac sodium

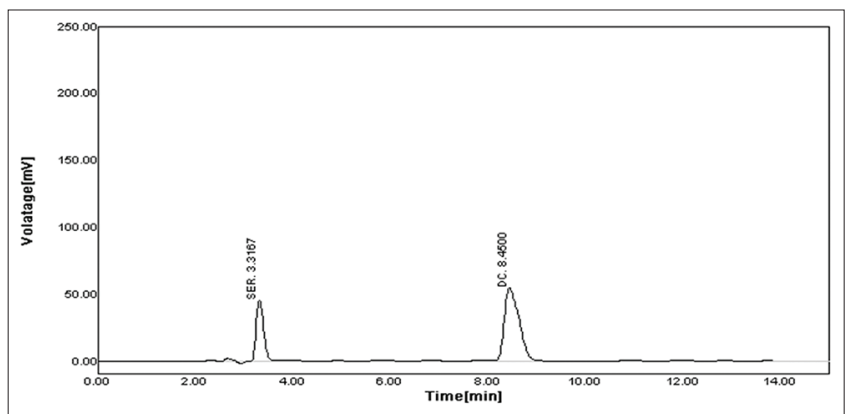

Fig. 3: Reversed-phase high-performance liquid chromatography graph of bulk mixture $(10 \mu \mathrm{g} / \mathrm{mL}$ SER and $50 \mu \mathrm{g} / \mathrm{mL}$ DC). Buffer (pH-7) with OPA:methanol:ACN (5:4:1 v/v/v), flow rate: $1.0 \mathrm{~mL} / \mathrm{min}$

The drug was dissolved in $10 \mathrm{~mL}$ of buffer pH-7.0 (HPLC grade) with shaking and sonicated for $10 \mathrm{~min}$

\section{Preparation of tablet stock solution}

An accurately weighed powder sample equivalent to $50 \mathrm{mg}$ of DC and $10 \mathrm{mg}$ of SER was transferred to $10 \mathrm{~mL}$ volumetric flask; $10 \mathrm{~mL}$ of phosphate buffer pH-7.0 was added and the flask was sonicated for $5 \mathrm{~min}$. The solution was filtered through $0.45 \mu$ membrane filter paper. From the prepared solution, $0.1 \mathrm{~mL}$ of the filtrate was transferred to $100 \mathrm{~mL}$ volumetric flask, and volume was made with mobile phase to get final concentration $50 \mu \mathrm{g} / \mathrm{mL}$ for DC and $10 \mu \mathrm{g} / \mathrm{mL}$ for SER.

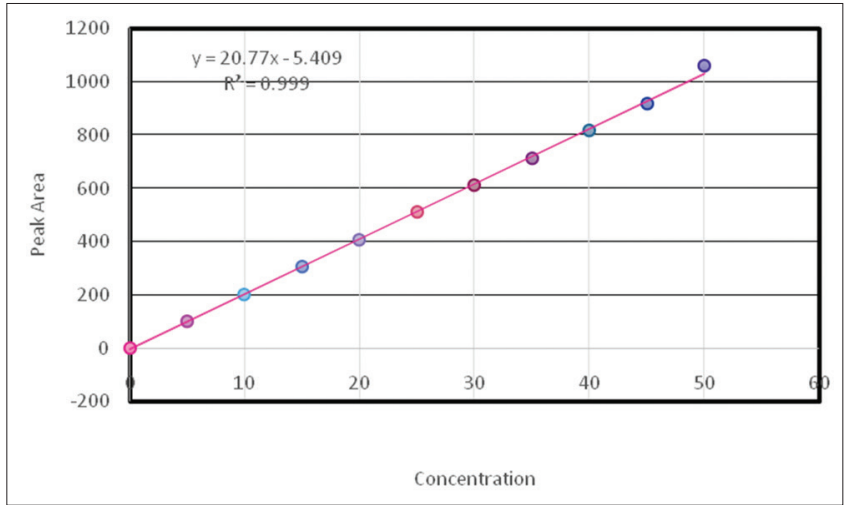

Fig. 4: Standard calibration curve of diclofenac

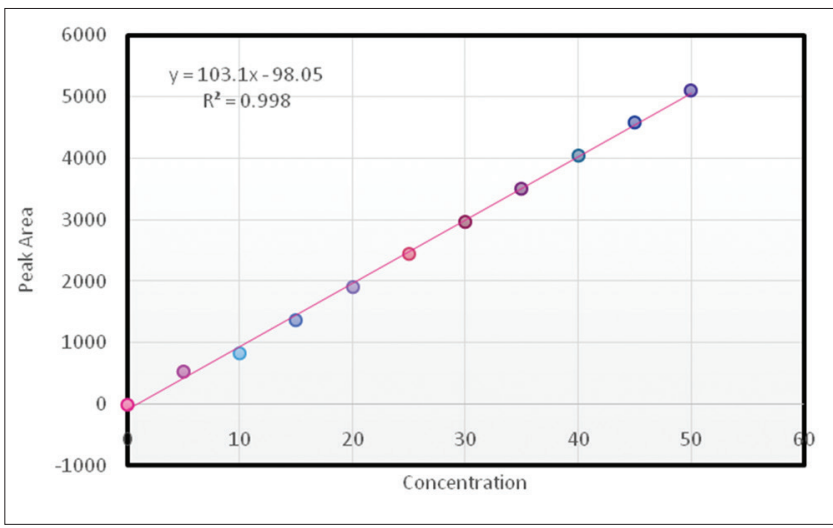

Fig. 5: Standard calibration curve of serratiopeptidase

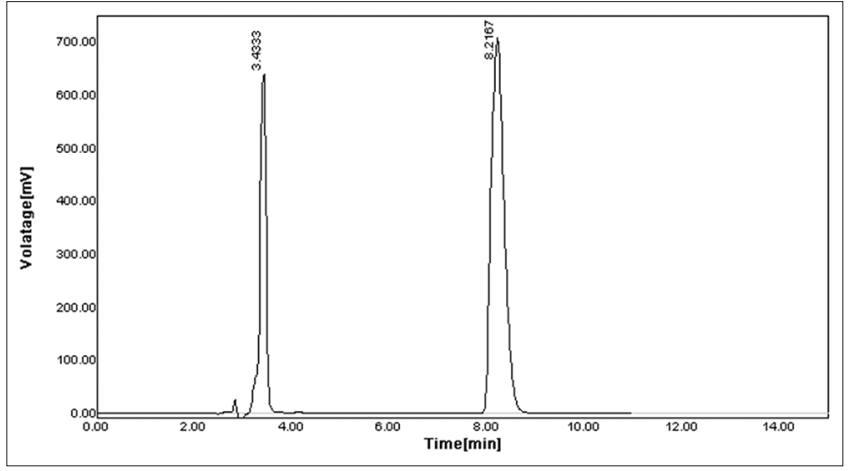

Fig. 6: Flow rate change - robustness: (1) Flow rate - $0.9 \mathrm{~mL}$

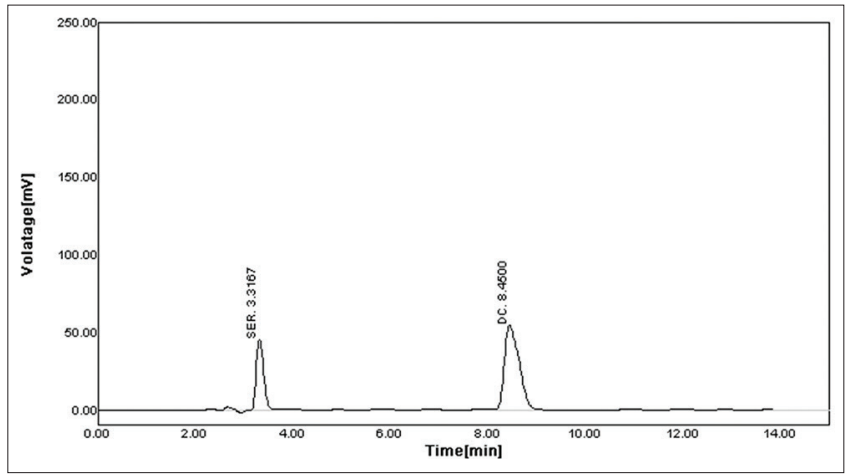

Fig. 7: Flow rate change - robustness: (2) Flow rate - $1.0 \mathrm{~mL}$ 


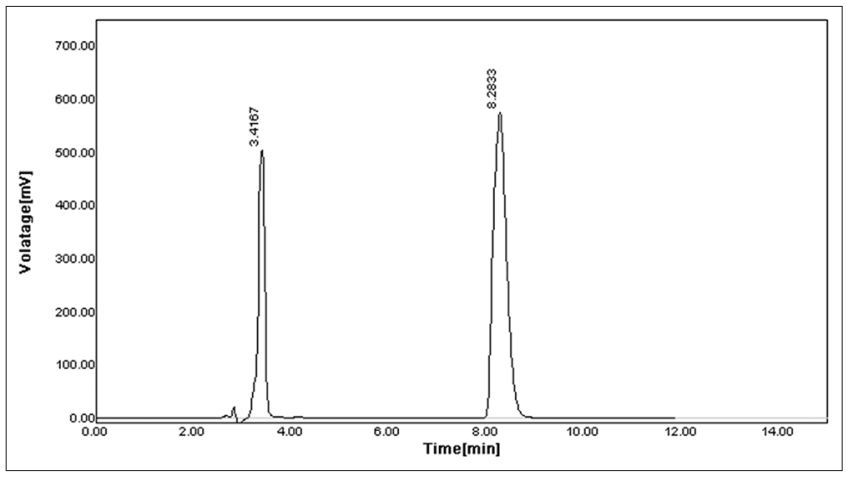

Fig. 8: Flow rate change - robustness: (3) Flow rate - 1.1 mL

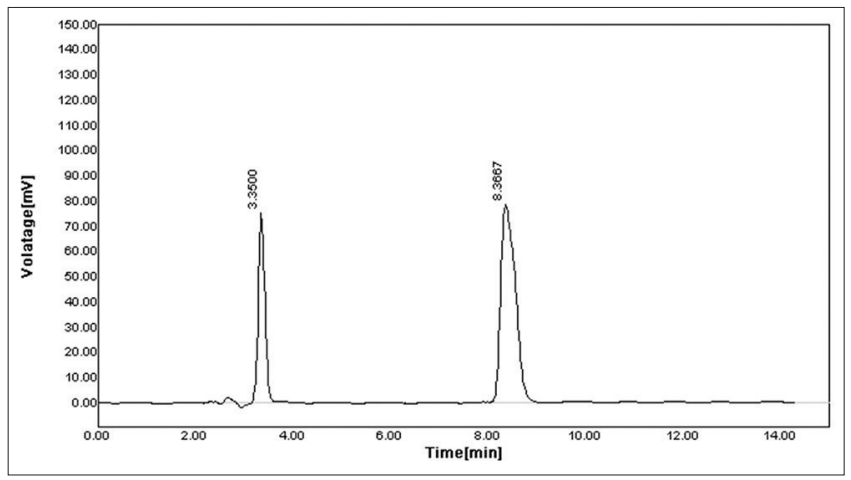

Fig. 9: Composition change: $9 \%$ acetonitrile $+42 \% \mathrm{MeOH}+49 \%$ buffer

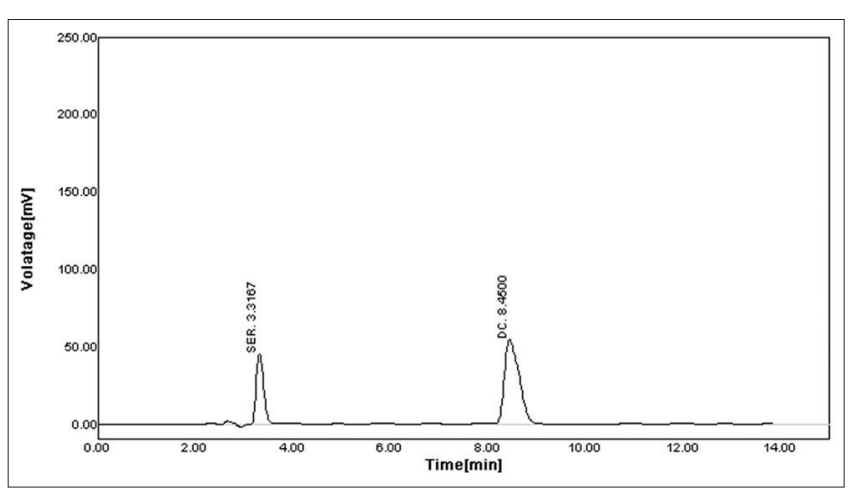

Fig. 10: Composition change $-10 \%$ acetonitrile $+40 \% \mathrm{MeOH}+$ $50 \%$ buffer

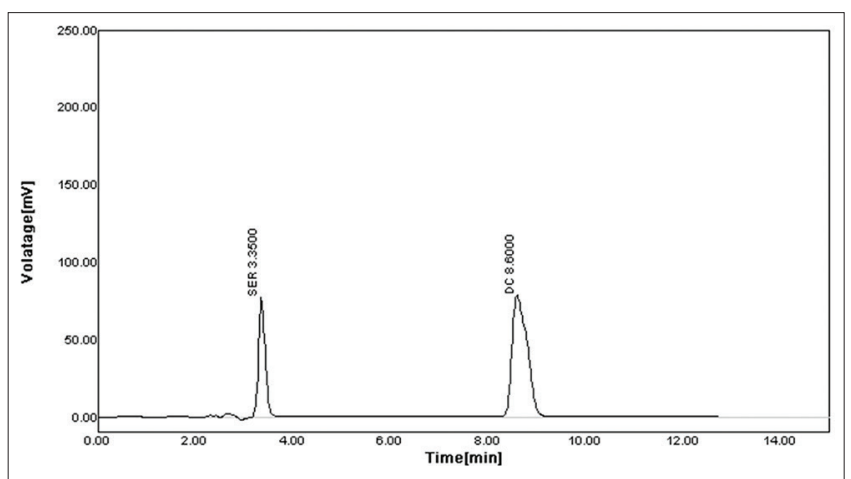

Fig. 11: Composition change $-11 \%$ acetonitrile $+38 \% \mathrm{MeOH}+$ $51 \%$ buffer

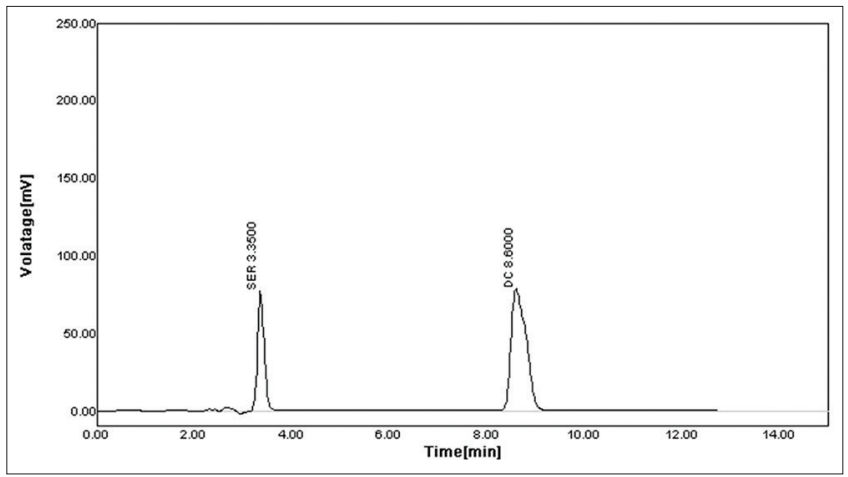

Fig. 12: Wavelength change: At $269 \mathrm{~nm}$

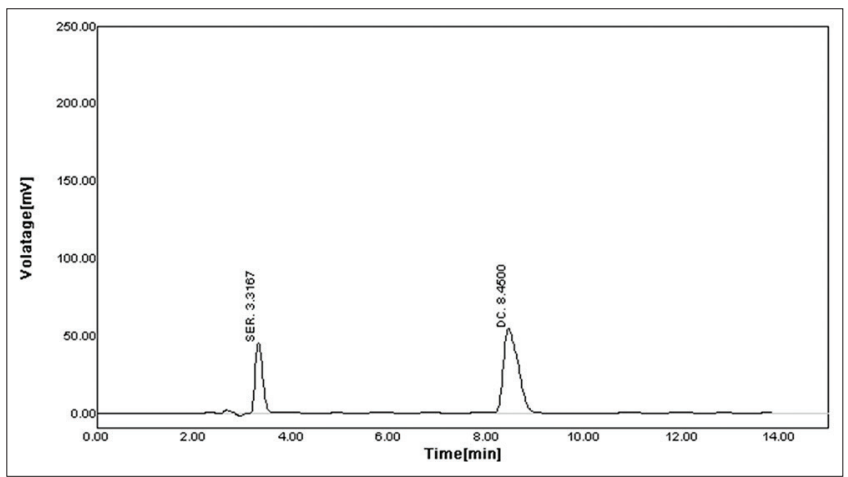

Fig. 13: Wavelength change: At $270 \mathrm{~nm}$

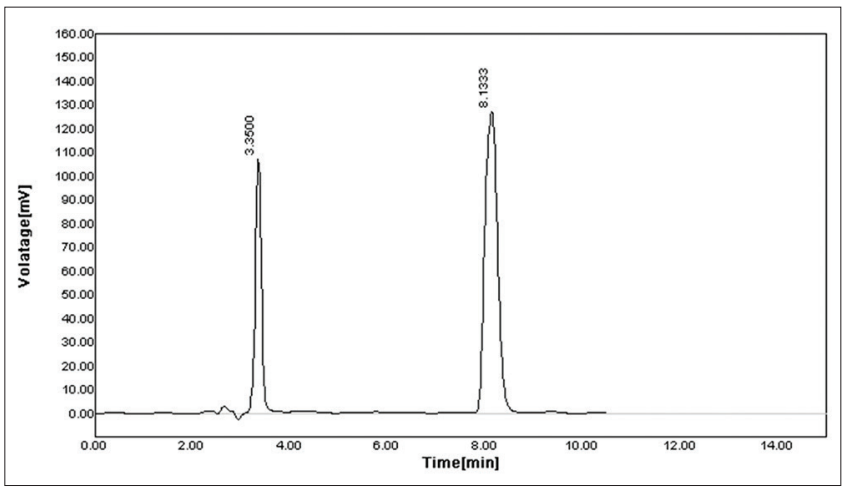

Fig. 14: Wavelength change: At $271 \mathrm{~nm}$. The method was found to be robust as there was no significant change in retention times

Preparation of mix working standard solution of SER and DC

Working standard solution was prepared by diluting $0.1 \mathrm{~mL}$ of stock solution SER and $0.5 \mathrm{~mL}$ of stock solution DC with diluents in $10 \mathrm{~mL}$ of volumetric flask up to the mark with mobile phase. To get $10 \mu \mathrm{g} / \mathrm{mL}$ for SER and $50 \mu \mathrm{g} / \mathrm{mL}$ for DC.

\section{Preparation of tablet mixture}

Tablet mixtures were prepared by pipetting out $0.1 \mathrm{~mL}$ from stock solution in $100 \mathrm{~mL}$ volumetric flask and diluted it with mobile phase upto the mark.

\section{Preparation of mix sample solution of SER and DC}

Working sample solutions were prepared by taking aliquots as mentioned in Table 1 from stock solution in $10 \mathrm{~mL}$ of volumetric flask and volume was made up to the mark with diluent to get 5-50 $10 \mu \mathrm{g} /$ $\mathrm{mL}$ concentrations of SER and DC (Table 1). 
Table 1: Preparation of mix working standard solution of SER and DC

\begin{tabular}{lllll}
\hline \multirow{2}{*}{ Concentration $(\mu \mathrm{g} / \mathbf{m L})$} & & & \multicolumn{2}{l}{ Volume $(\mathbf{m L})$} \\
\cline { 5 - 5 } SER & DC & & SER & DC \\
\hline 5 & 5 & & 0.05 & 0.05 \\
10 & 10 & & 0.1 & 0.1 \\
15 & 15 & & 0.15 & 0.15 \\
20 & 20 & & 0.2 & 0.2 \\
25 & 25 & 0.25 & 0.25 \\
30 & 30 & & 0.3 & 0.3 \\
35 & 35 & & 0.35 & 0.35 \\
40 & 40 & & 0.4 & 0.4 \\
45 & 45 & 0.45 & 0.45 \\
50 & 50 & 0.5 & 0.5 \\
\hline
\end{tabular}

Table 2: Analysis of pure mixed standards of DC and SER

\begin{tabular}{|c|c|c|c|c|c|}
\hline \multicolumn{2}{|c|}{$\begin{array}{l}\text { Concentration of } \\
\text { drugs taken }(\mu \mathrm{g} / \mathrm{mL})\end{array}$} & \multicolumn{2}{|c|}{$\begin{array}{l}\text { Concentration of } \\
\text { drugs found }(\mu \mathrm{g} / \mathrm{mL})\end{array}$} & \multicolumn{2}{|c|}{$* \%$ drug found } \\
\hline SER & DC & SER & DC & SER & DC \\
\hline 10 & 50 & 9.22 & 48.34 & 92.2 & 96.68 \\
\hline
\end{tabular}

*Average of five determination. Buffer (pH-7) with OPA: methanol: ACN (5:4:1 $\mathrm{v} / \mathrm{v} / \mathrm{v}$ ) with Flow rate: $1.0 \mathrm{ml} / \mathrm{min}$ was selected, ACN: Acetonitrile

Table 3: Standard calibration data for DC

\begin{tabular}{ll}
\hline DC sodium & \\
\hline Concentration $(\mu \mathrm{g} / \mathrm{mL})$ & Peak area* \\
\hline 5 & 85.05 \\
10 & 130.60 \\
15 & 261.2 \\
20 & 391.7 \\
25 & 520.6037 \\
30 & 651.2037 \\
35 & 781.8037 \\
40 & 912.3937 \\
45 & 1043.0037 \\
50 & 1188.1166 \\
\hline
\end{tabular}

Table 4: Standard calibration data for SER

\begin{tabular}{ll}
\hline SER & \\
\hline Concentration $(\mu \mathrm{g} / \mathbf{m L})$ & Peak area* \\
\hline 5 & 535.54 \\
10 & 831.2185 \\
15 & 1366.75 \\
20 & 1901.74 \\
25 & 2437.29 \\
30 & 2972.80 \\
35 & 3508.37 \\
40 & 4043.90 \\
45 & 4579.45 \\
50 & 5114.45 \\
\hline SER: Serratiopeptidase
\end{tabular}

Selection of mobile phase

Mixed solution of SER and DC was prepared and injected into the HPLC system. The solution was analyzed using buffer:methanol:ACN.

\section{Selection of flow rate}

Chromatogram of a mixed solution of SER $(10 \mu \mathrm{g} / \mathrm{mL})$ and DC $(50 \mu \mathrm{g} / \mathrm{mL})$ was studied at different flow rate such as $0.9,1$, and $1.1 \mathrm{~mL} / \mathrm{min}$
Table 5: Statistical data for SER and DC by chromatographic method

\begin{tabular}{lll}
\hline Parameters & SER & DC \\
\hline Linearity range $(\mu \mathrm{g} / \mathrm{mL})$ & $5-50$ & $5-50$ \\
Correlation coefficient & 0.998 & 0.999 \\
Slope & 103.1 & 20.77 \\
Intercept & 98.05 & 5.409 \\
LOD $(\mu \mathrm{g} / \mathrm{mL})$ & 0.215 & 0.542 \\
\hline
\end{tabular}

Linearity range for both SER and DC was found to be $5-50 \mu \mathrm{g} / \mathrm{mL}$

SER: Serratiopeptidase, DC: Diclofenac, LOD: Limit of detection, LOQ: Limit of quantitation

Table 6: Repeatability data (statistical evaluation) bulk mix

\begin{tabular}{llll}
\hline Drugs & $* \%$ Mean & *SD & *\% RSD \\
\hline SER & 92.32 & 0.0454 & 0.0491 \\
DC & 94.12 & 0.6401 & 0.6800 \\
\hline
\end{tabular}

*Average of five determinations, SER: Serratiopeptidase, DC: Diclofenac

Table 7: Repeatability data (statistical evaluation) tablet mix

\begin{tabular}{llll}
\hline Drugs & $* \%$ Mean & $*$ SD & $* \%$ RSD \\
\hline SER & 92.9 & 0.096 & 0.103 \\
DC & 94.04 & 0.640 & 0.680
\end{tabular}

*Average of five determinations. The $\%$ RSD is $<2$ for SER and DC which indicate that the method is precise, SER: Serratiopeptidase, DC: Diclofenac

Selection of analytical wavelength

The standard solutions of SER $(10 \mu \mathrm{g} / \mathrm{mL})$ and DC $(50 \mu \mathrm{g} / \mathrm{mL})$ in mobile phase were scanned separately in the UV region of $200-400 \mathrm{~nm}$, and the overlain spectra were recorded.

\section{Chromatographic separation}

Standard or sample solution of $20 \mu \mathrm{L}$ was injected into the column. The chromatogram was run for 15 min with mobile phase, phosphate buffer pH 7 with OPA:methanol:ACN (5:4:1 v/v/v), which was previously sonicated for $10 \mathrm{~min}$ and detection done at wavelength $270 \mathrm{~nm}$. The chromatogram was stopped after the separation was achieved completely. Data related to peak suc as area, height, retention time, and resolution were recorded using software.

\section{Calibration curve for SER and DC}

Aliquots of mix working standard solution of SER $(5-50 \mu \mathrm{g} / \mathrm{mL})$ and DC (5-50 $\mu \mathrm{g} / \mathrm{mL})$ were injected into the system with stated chromatographic conditions as described under table. The graph of the area of peak obtained versus respective concentration was plotted. The mean area and its standard deviation (SD) were calculated.

\section{Validation of proposed method [5-15]}

Precision

Repeatability

For repeatability, the separate concentration of $10 \mu \mathrm{g} / \mathrm{mL}$ for SER and $50 \mu \mathrm{g} / \mathrm{mL}$ for DC was analyzed 5 times on the same day and \% relative SD (\% RSD) were calculated.

\section{Intraday precision}

Separate concentration of $10 \mu \mathrm{g} / \mathrm{mL}$ for SER and $50 \mu \mathrm{g} / \mathrm{mL}$ for DC was analyzed 5 times on the same day and \% RSD was calculated.

\section{Interday precision}

Separate concentration of $10 \mu \mathrm{g} / \mathrm{mL}$ for SER and $50 \mu \mathrm{g} / \mathrm{mL}$ for DC was analyzed 5 times on the different days and \% RSD was calculated. 
Table 8: Inter- and intra-day precision

\begin{tabular}{|c|c|c|c|c|c|c|}
\hline \multirow[t]{2}{*}{ Drugs } & \multicolumn{3}{|c|}{ Inter-day } & \multicolumn{3}{|l|}{ Intraday } \\
\hline & \%Mean & SD & \%RSD & \%Mean & SD & $\%$ RSD \\
\hline SER (BULK) & 92.42 & 0.0516 & 0.0558 & 93.04 & 0.0472 & 0.0507 \\
\hline DC (BULK) & 94.12 & 0.6401 & 0.6800 & 94.12 & 0.6422 & 0.6823 \\
\hline DC (TABLET) & 93.86 & 0.6386 & 0.6803 & 93.87 & 0.6386 & 0.6803 \\
\hline
\end{tabular}

*Average of five determinations. The \% RSD is <2 for SER \& DC which indicate that the method is precise, SER: Serratiopeptidase, DC: Diclofenac

Table 9: Statistical validation of recovery studies

\begin{tabular}{|c|c|c|c|c|c|c|}
\hline \multirow[t]{2}{*}{$\begin{array}{l}\text { Level of \% } \\
\text { recovery }\end{array}$} & \multicolumn{2}{|c|}{$\begin{array}{l}\text { \% Mean } \\
\text { recovery* }\end{array}$} & \multicolumn{2}{|l|}{ SD } & \multicolumn{2}{|l|}{ \% RSD } \\
\hline & SER & DC & SER & DC & SER & DC \\
\hline 80 & 92.74 & 98.92 & 0.0589 & 0.0152 & 0.063 & 0.0153 \\
\hline 100 & 98.1 & 99.51 & 0.635 & 0.0115 & 0.647 & 0.0115 \\
\hline 120 & 98.12 & 98.56 & 0.230 & 0.0057 & 0.234 & 0.0057 \\
\hline
\end{tabular}

*Average of three at each level of recovery. The \% recovery is within limit $(98.0-$ $102.0 \%)$, so the method is accurate, SER: Serratiopeptidase, DC: Diclofenac

\section{Accuracy}

Procedure

Preparation of sample solution for SER

Recovery studies were carried out by pipetting out $0.1 \mathrm{~mL}$ from tablet stock solution in $10 \mathrm{~mL}$ volumetric flask and in that $0.8 \mathrm{~mL}(80 \%)$, $1.0 \mathrm{~mL}(100 \%)$, and $1.1 \mathrm{~mL}(120 \%)$ bulk mixtures of DC and SER were added, and area was measured at the selected maximum wavelength.

The accuracy of the method was performed by conducting the standard edition method $(80 \%, 100 \%$, and $120 \%$ level) of tablet. The percentage recoveries were calculated and reported with SD and \% RSD.

\section{Specificity}

The specificity of the HPLC method was ascertained by analyzing standard drug and sample solutions. The retention times of SER and DC in the sample solution were confirmed by comparing with that of the respective standards. The chromatogram of tablet sample showed only two peaks at retention time of 3.3833 and $8.1667 \mathrm{~min}$ for SER and DC, respectively, indicating that there is no interference of the excipients in the tablet formulation.

\section{Limit of detection (LOD) and limit of quantitation (LOQ)}

The LOD and LOQ were estimated from the set of three calibration curves used to determine method linearity. The LOD and LOQ were calculated as follows,

$\mathrm{LOD}=\frac{3.3 \sigma}{\mathrm{S}} \quad \mathrm{LOQ}=\frac{10 \sigma}{\mathrm{S}}$

Where $\sigma=$ SD of replication, $\mathrm{S}=$ slope of calibration curve

\section{System suitability}

Combined standard solution of SER $(10 \mu \mathrm{g} / \mathrm{mL})$ and DC $(50 \mu \mathrm{g} / \mathrm{mL})$ was prepared and analyzed 3 times. Chromatograms were studied for different parameters such as tailing factor, resolution, and theoretical plates to see that whether they comply with the recommended limit or out of recommended limit.

\section{Analysis of tablet dosage form}

An accurately weighed powder sample equivalent to $50 \mathrm{mg}$ of DC and $10 \mathrm{mg}$ of SER was transferred to $10 \mathrm{~mL}$ volumetric flask; $10 \mathrm{~mL}$ of phosphate buffer pH-7.0 was added, and the flask was sonicated for $5 \mathrm{~min}$. Solution was filtered through $0.45 \mu$ membrane filter paper.
From the prepared solution, $0.1 \mathrm{~mL}$ of the filtrate was transferred to $100 \mathrm{~mL}$ volumetric flask, and volume was made with mobile phase to get final concentration $50 \mu \mathrm{g} / \mathrm{mL}$ for DC and $10 \mu \mathrm{g} / \mathrm{mL}$ for SER. After setting the chromatographic conditions and stabilizing the instrument to obtain a steady baseline, the tablet sample solution was injected using $20 \mu \mathrm{L}$ syringe filter. Chromatographic detection was carried out at $270 \mathrm{~nm}$. Chromatogram was obtained, and peak areas were recorded. The procedure was repeated 5 times for the analysis of homogeneous sample.

\section{RESULTS AND DISCUSSION}

\section{Selection of mobile phase}

Buffer (pH-7) with OPA:methanol:ACN (5:4:1 v/v/v) was selected as mobile phase with flow rate $1.0 \mathrm{ml} / \mathrm{min}$. The chromatogram is shown in Fig. 3. The proposed method was applied on 5 mixtures of SER and DC. The concentrations obtained are shown in Table 2.

\section{Validation of proposed method}

Linearity

The linearity range for SER and DC was found to be $5-50 \mu \mathrm{g} / \mathrm{mL}$.

The linearity graphs and correlation coefficients are shown in Figs. 4 and 5 for DC and SER. The data for calibration is given in Tables 3 and 4. The statistical data for linearity studies is given in Table 5 .

\section{Precision}

The statistical data for repeatability studies for bulk mixture and tablet mixture are given in Tables 6 and 7 .

\section{Intra- and inter-day precision}

Intraday precision was determined by analyzing SER and DC for 3 times in the same day. Interday precision was determined by analyzing SER and DC daily for different days. The results for inter-day and intra-day precision studies are shown in Table 8.

\section{Accuracy}

Recovery studies were carried out by applying the method of standard drug addiction at $80 \%, 100 \%$, and $120 \%$ levels. The solutions for recovery studies at $80 \%, 100 \%$, and $120 \%$ level were prepared. The solutions were filtered through a $0.45-\mu \mathrm{m}$ membrane filter paper and analyzed by RP-HPLC method. At each level of recovery, three determinations were performed. The results of the same are shown in Table 9. The proposed method was found to be accurate.

\section{Robustness}

Robustness of the proposed method was studied by changing flow rate of mobile phase $(0.9 \mathrm{ml} / \mathrm{min}, 1.0 \mathrm{ml} / \mathrm{min}$ and $1.1 \mathrm{ml} / \mathrm{min})$, changing the composition of the mobile phase $(9 \%$ acetonitrile $+42 \%$ $\mathrm{MeOH}+49 \%$ buffer, $10 \%$ acetonitrile $40 \% \mathrm{MeOH}+50 \%$ buffer and $11 \%$ acetonitrile $+38 \% \mathrm{MeOH}+51 \%$ buffer) and by changing the detection wavelength $(269 \mathrm{~nm}, 270 \mathrm{~nm}$ and $271 \mathrm{~nm})$. The chromatograms with changed flow rates are shown in Figs. 6-8. The chromatograms with changed mobile phase compositions are shown in Figs. 9-11. The chromatograms with changed detection wavelengths are shown in Figs. 12-14. The statistical data for retention times and tailing factors for 
Table 10: Flow rate change

\begin{tabular}{|c|c|c|c|c|c|c|c|c|}
\hline \multirow[t]{2}{*}{ Flow rate } & \multicolumn{2}{|c|}{ Retention time } & \multicolumn{2}{|c|}{ Tailing factor } & \multicolumn{2}{|l|}{ Area } & \multicolumn{2}{|c|}{$\%$ Content } \\
\hline & SER & DC & SER & DC & SER & DC & SER & DC \\
\hline 0.9 & 3.4333 & 8.2167 & 0.7333 & 1.2333 & 1150.2328 & 2389.3639 & 101.5 & 101.88 \\
\hline 1.1 & 3.4167 & 8.2833 & 0.7667 & 1.2000 & 1035.22 & 2133.2555 & 101.36 & 99.89 \\
\hline
\end{tabular}

Table 11: Composition change

\begin{tabular}{|c|c|c|c|c|c|c|c|c|}
\hline \multirow[t]{2}{*}{ Composition change } & \multicolumn{2}{|c|}{ Retention time } & \multicolumn{2}{|c|}{ Tailing factor } & \multicolumn{2}{|l|}{ Area } & \multicolumn{2}{|c|}{ \%Content } \\
\hline & SER & DC & SER & DC & SER & DC & SER & DC \\
\hline $42 \% \mathrm{MeOH}+9 \% \mathrm{ACN}+49 \%$ BUFFER & 3.3500 & 8.3667 & 1.1000 & 1.4615 & 756.57 & 1646.64 & 73.34 & 77.57 \\
\hline CAN (10\%)+MeOH (40\%)+BUFFER (50\%) PH 7.0 & 3.3167 & 8.4500 & 1.3889 & 1.4286 & 831.2185 & 1988.1166 & 92.5 & 96.62 \\
\hline $38 \% \mathrm{MeOH}+11 \% \mathrm{ACN}+51 \%$ BUFFER & 3.3500 & 8.6000 & 1.1667 & 1.3929 & 786.3861 & 1643.9059 & 76.23 & 79.97 \\
\hline
\end{tabular}

SER: Serratiopeptidase, DC: Diclofenac, ACN: Acetonitrile

Table 12: Wavelength change

\begin{tabular}{|c|c|c|c|c|c|c|c|c|}
\hline \multirow[t]{2}{*}{ Wavelength change } & \multicolumn{2}{|c|}{ Retention time } & \multicolumn{2}{|c|}{ Tailing factor } & \multicolumn{2}{|l|}{ Area } & \multicolumn{2}{|c|}{$\%$ Content } \\
\hline & SER & DC & SER & DC & SER & DC & SER & DC \\
\hline 269 & 3.3500 & 8.6000 & 1.1663 & 1.3919 & 776.3875 & 1643.8069 & 75.26 & 76.97 \\
\hline 271 & 3.3500 & 8.1333 & 1.0000 & 1.0625 & 1276.552 & 2303.7380 & 109.76 & 107.87 \\
\hline
\end{tabular}

SER: Serratiopeptidase, DC: Diclofenac

Table 13: Details of chromatogram of DC and SER in tablet mix

\begin{tabular}{lllll}
\hline Name & Rt (min) & Area & $\begin{array}{l}\text { Tailing } \\
\text { factor }\end{array}$ & $\begin{array}{l}\text { Theoretical } \\
\text { plate }\end{array}$ \\
\hline SER & 3.3833 & 1031.4727 & 0.9444 & 3570.5 \\
DC & 8.1667 & 2135.55 & 1.0625 & 3328.5 \\
\hline
\end{tabular}

SER: Serratiopeptidase, DC: Diclofenac

Table 14: Assay results of marketed dosage forms

\begin{tabular}{|c|c|c|c|c|c|}
\hline \multicolumn{2}{|c|}{$\begin{array}{l}\text { Label } \\
\text { claim (mg/tab) }\end{array}$} & \multicolumn{2}{|c|}{$\begin{array}{l}\text { Amount } \\
\text { found (mg/tab) }\end{array}$} & \multicolumn{2}{|c|}{$\%$ of label claim } \\
\hline SER & DC & SER & DC & SER & DC \\
\hline 10 & 50 & 9.31 & 46.42 & 93.1 & 92.84 \\
\hline 10 & 50 & 9.23 & 47.50 & 92.3 & 95 \\
\hline 10 & 50 & 9.24 & 46.64 & 92.4 & 93.28 \\
\hline 10 & 50 & 9.22 & 47.55 & 92.2 & 95.1 \\
\hline 10 & 50 & 9.31 & 47.87 & 93.1 & 95.74 \\
\hline
\end{tabular}

SER: Serratiopeptidase, DC: Diclofenac

Table 15: Validation parameters

\begin{tabular}{lll}
\hline Parameters & SER & DC \\
\hline Linearity range $(\mu \mathrm{g} / \mathrm{mL})$ & $5-50$ & $5-50$ \\
Correlation coefficient & 0.998 & 0.999 \\
$\mathrm{LOD}(\mu \mathrm{g} / \mathrm{mL})$ & 0.215 & 0.542 \\
$\mathrm{LOQ}(\mu \mathrm{g} / \mathrm{mL})$ & 0.653 & 1.643 \\
Precision: bulk Intraday (\% RSD) & 0.0507 & 0.6823 \\
Interday (\% RSD) & 0.0558 & 0.6800 \\
Precision: Tablet intraday (\% RSD) & 0.0518 & 0.6803 \\
Interday (\% RSD) & 0.0553 & 0.6803 \\
Tailing factor & 1.3889 & 1.4286 \\
Mean \% recovery bulk & 92.32 & 94.12 \\
Mean \% recovery tablet & 92.9 & 94.04 \\
Theoretical plates & 1814.8 & 2945.0 \\
\hline
\end{tabular}

SER: Serratiopeptidase, DC: Diclofenac, LOD: Limit of detection, LOQ: Limit of quantitation

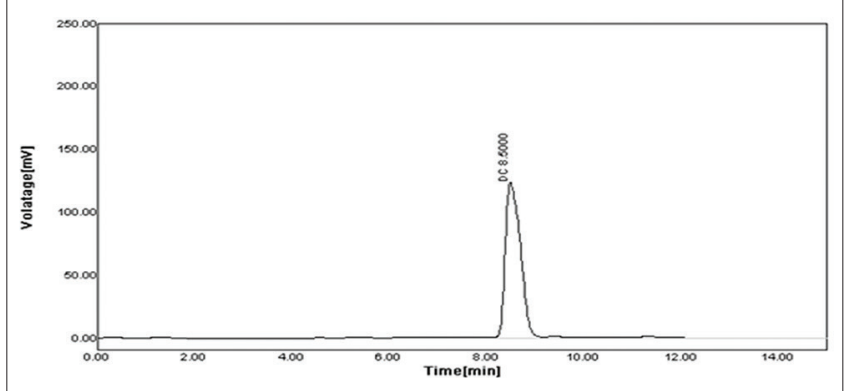

Fig. 15: Chromatogram of diclofenac

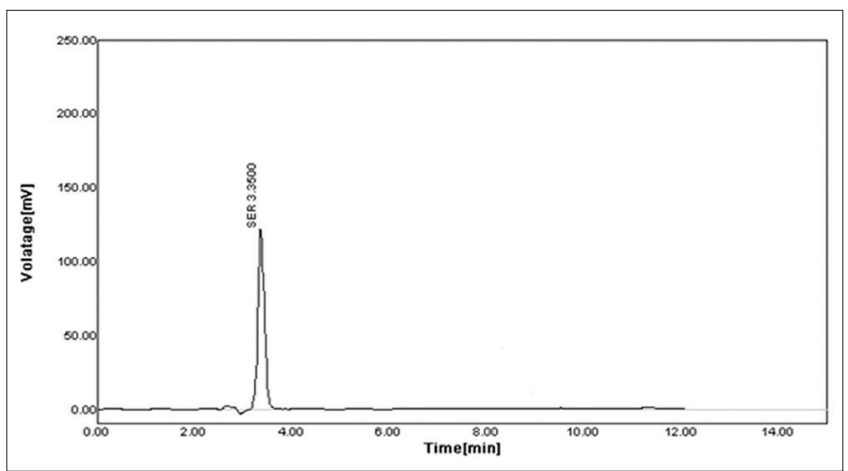

Fig. 16: Chromatogram of serratiopeptidase

the flow rate change, mobile phase composition change and detection wavelength change are shown in Tables 10-12. The retention time is not affected significantly. Thus, the proposed method was found to be robust.

\section{Specificity}

By comparing the chromatogram of diluent, standard solution, and test preparation solution, it was observed that there was no any interference of excipients with the peak of SER and DC, as shown in Figs. 15-17. 


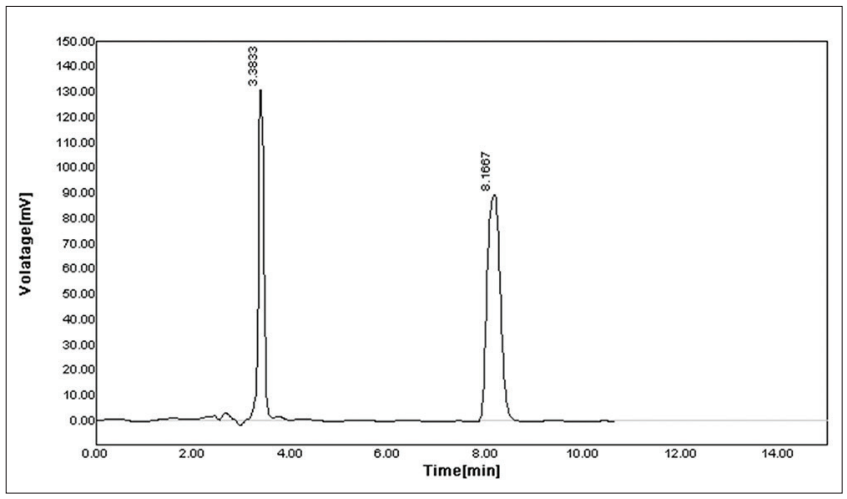

Fig. 17: Chromatogram of tablet mixture serratiopeptidase $(10 \mu \mathrm{g} / \mathrm{mL})$ and diclofenac $(50 \mu \mathrm{g} / \mathrm{mL})$

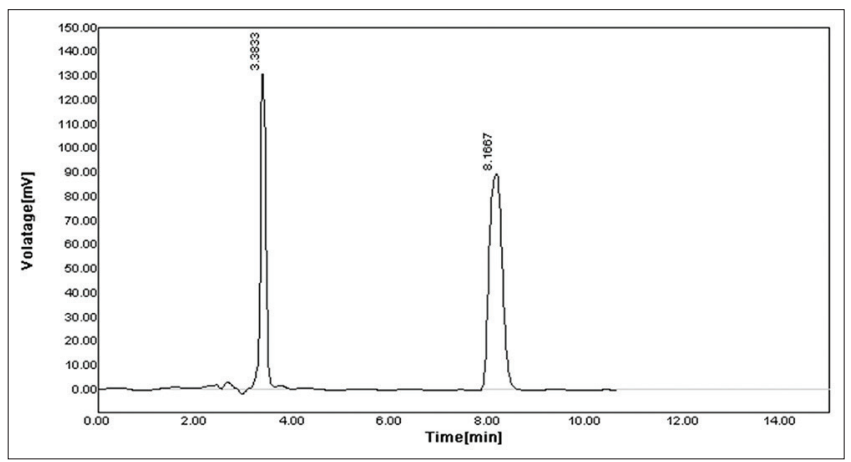

Fig. 18: Chromatogram of tablet mixture

\section{System suitability data}

The system suitability data is shown in Table 13 .

\section{Application of the developed method to tablet formulation}

The proposed validated method was successfully applied to the determination of SER and DC in its tablet dosage form (Fig. 18).

\section{Summary of validation parameters}

Summary of the validation parameters studied is given in Table 15. The proposed method was validated as per ICH Q2R1 guidelines.

\section{DISCUSSION}

The literature survey gives few reported RP-HPLC methods for simultaneous estimation of DC sodium and SER in bulk and tablet dosage form. This work has made an attempt to develop a new RP-HPLC method for the estimation of DC sodium and SER in bulk and tablet dosage form. This work reports in detail, a more rigorously studied RP-HPLC method.

\section{CONCLUSION}

The proposed work concludes that the developed RP-HPLC method is simple, accurate, rapid, sensitive, precise, and economic. Hence, this method can be employed successfully for the estimation of SER and DC sodium in both bulk and tablet dosage forms.

\section{AUTHORS' CONTRIBUTION}

Experimental design, guidance, supervision, and review work for the research were done by Dr.Anagha Joshi M., Principal, SCES's Indira College of Pharmacy, Tathawade, Pune. Experimental work, interpretation of result, and writing of this manuscript were done by Manasi Kulkarni B., PhD Research Scholar, Punnaiyah Ramajayam Institute of Science and Technology, PRIST Deemed to be University, Thanjavur, Tamilnadu and Assistant Professor, SCES's Indira College of Pharmacy, Tathawade, Pune. All authors read and approve the final manuscript.

\section{CONFLICTS OF INTEREST}

The authors do not report any conflicts of interest.

\section{REFERENCES}

1. Sharma DA, Laxman MP, Amit KJ, Mahammadali LK, Prashant TR, Dhaval P, et al. RP-HPLC method for the simultaneous estimation of serratiopeptidase and nimesulide in their bulk and combined dosage form. Int J Univers Pharm Bio Sci 2014;3:175-95.

2. Ministry of Health and Family Welfare. Indian Pharmacopoeia. Vol. 2. New Delhi: Ministry of Health and family welfare, Govt. of India, Controller of publications; 1996. p. 1158.

3. Kaviyarasi NS, Prashantha N, Suryanarayanad VS. In-silico analysis of inhibitor and substrate binding site of serrapeptidase from Serratia marcescens MTCC 8708. Int J Pharm Pharm Sci 2016;8:123-8.

4. Wagdarikar JM, Joshi MA, Ghorpade NA. UV visible spectrophotometric method for the simultaneous estimation of serratiopeptidase and diclofenac sodium in their bulk and combined dosage form. Int J Pharm Sci Res 2015;6:2013-18.

5. International Conference on Harmonization of Technical Requirements for Registration of Pharmaceuticals for Human Use; 2003. ICH, Q2B: Stability Testing of New Drug Substances and Product; 2003.

6. Rajoriya V, Soni A, Kashaw V. Method development and validation of fast dissolving tablet of ramipril by HPLC method. Int J Pharm Pharm Sci 2016;8:174-8.

7. Beckett AH, Stenlake JB. Practical Pharmaceutical Chemistry. Part 2. $4^{\text {th }}$ ed. New Delhi: CBS Publishers and Distributors; 2004. p. 284-95.

8. Jeffery GH, Bassat J, Mendham J, Denny RC. Vogel's Textbook of Quantitative Chemical Analysis. $6^{\text {th }}$ ed. Harlow: ELBS with Longman publication; 1989. p. 1-6, 99-112, 290-93.

9. Robert NA, Alfred WH. Pharmaceutical Process Validation. $3^{\text {rd }}$ ed., Vol. 129. New York: Marcel Dekker; 2003. p.507-22.

10. Government of India, Ministry of Health and Family Welfare, The Indian Pharmacopoeia Commission. Indian Pharmacopoeia 2007. Vol. 1 and 2. New Delhi: The Indian Pharmacopoeia Commission; 2007. p. 632

11. Skoog DA, West DM, Holler FJ, Crounch S. Fundamentals of Analytical Chemistry. $8^{\text {th }}$ ed. London: Thomsan Asia Pvt Ltd.; 2004. p. 160-167, 971-95.

12. Sethi PD. HPLC-High Performance Liquid ChromatographyQuantitative Analysis of Pharmaceutical Formulations. $1^{\text {st }}$ ed. New Delhi: CBS Publication; 2001. p. 3-135.

13. Satinde RA, Michael DW. Handbook of Pharmaceutical Analysis by HPLC. Vol. 6. Amsterdam, Boston: Elsevier Academic press; 2005. p. $19-44,47-69,197-210$

14. Gary CD. Analytical Chemistry. $6^{\text {th }}$ ed. New Jersey: Wiley India Edition; 2007. p. 604-16.

15. Michael SE, Ira KS. Analytical Method Development and Validation. New York: Marcel Dekker; 1997. p. 53-67, 73. 